\title{
The Effect of Mental Toughness of Individuals Doing Outdoor Sports on their Decision-Making Skills
}

\author{
Burak GÜRER ${ }^{1}$, Enise Merve KARABABA ${ }^{1}$, Esra CANLI ${ }^{1}$ \\ ${ }^{1}$ Gaziantep University, Physical Education and Sport, Gaziantep / TURKEY \\ Address Correspondence to Burak GÜRER e-mail: e-mail: burakgurer27@gmail.com
}

\begin{abstract}
This study intends to examine the impact of the mental toughness of athletes doing outdoor sports on their decision-making skills. The study population is composed of 504 athletes doing outdoor sports in various disciplines in Turkey in 2017. The mental toughness in sports scale developed by Sheard et al. (29) and adapted to Turkish by Altıntaş and Bayar Koruç (1) and the Melbourne Decision Making Scale I-II Scale developed by Mann et al. (35) and adapted to Turkish by Deniz (11) were used. The Independent Samples T test was used to analyze the data obtained as well as the One Way Analysis of Variance (One Way Anova) used in case of the existence of more than two groups and the correlation analysis for the relationship between the two groups. As a result, significant differences were found by the variables gender, marital status, age, educational status, the type of outdoor sports engaged in and experience. Accordingly, mental toughness has effects on decision-making skills when doing outdoor sports. There is a low level of positive correlation between mental toughness and decision-making skills. It is thought that the seasons and the types of outdoor sports done have an impact on these results.
\end{abstract}

Key words: Outdoor sports, mental toughness, decision-making

\section{INTRODUCTION}

Living and spending time in nature has its benefits (17). People turning to different sports have begun to choose among sports branches that give them joy and push their boundaries (38). Extreme sports, adventure sports, action sports, and even individual outdoor sports have shown a large increase in popularity over the last 20 years (28). Between 2000 and 2007, the number of people participating in one or more outdoor sports activities increased by $4.4 \%$, from 208 million to 217 million (7). Between 1990 and 2006, the number of members of the British Mountaineering Council increased by 37,514 (12, 2). On the basis of this exponential increase, investigators explored the benefits of doing outdoor sports and found that it has positive influences on taking responsibility, leadership skills, decision-making, trust, socialization, happiness and risk taking (34). Those who do outdoors sports often have agile personalities.
They are usually strong, tough, and welldisciplined people who have to make immediate and correct decisions (24).

Mental toughness is one of the most important psychological components for good performance and has recently attracted attention as an important study topic $(3,21,10)$. Mental toughness is positive psychological capacities that can help one recover in a number of negative situations such as mishaps, failures, conflict situations, or increased responsibility (25). Mentally resilient athletes tend to be highly competitive, decisive, self-motivated, focused in stressful situations, resilient in the face of difficulty, and highly self-confident even after failure (9). Mental strategies such as focus, mental stability, setting short-term goals, having a track record in climbing, knowledge of one's own body, feeling supported by other climbers and athletes, and believing in one's own capacity are crucial for success in climbing (4). Mental toughness is a 
clear strategy to cope with obstacles in nature and in the mountains. A mountain-climber climbing Everest once said, "Mental toughness is extremely important. Some people are more affected by high altitudes. There is no comfort at high altitudes, so you must be mentally and physically tough; otherwise you will have to go back" (4:19), pointing to the significance of mental toughness for dealing with challenges. Due to the inherent risk of injury and death, a tremendous amount of physical toughness and mental strength are necessary for a successful climb (14).

For every challenge nature presents, there is a counter-strategy that can be employed (4). Those who do outdoor sports and outdoor sports instructors are involved in complex decisionmaking environments and there are multiple factors in this decision-making environment (16). Decision-making is a dynamic process in which individuals play an active role. People who have to make a decision have to satisfy their inner needs as well as meet the expectations of those around them. To accomplish this, individuals must utilize their personal and environmental resources effectively and competently (36). Decision-making is defined as being able to select actions among others that are needed to achieve a specific goal (31). According to Maddi (33), the quest for meaning characterized by the existential approach of psychology involves continuous decision-making processes. When making a decision, people are left to choose between pursuing a well-trodden path in light of past experiences or exploring new, uncharted territory. For leaders of outdoor sports, decision-making is considered one of the most important skills that a professional should have, as in many other areas. Decision-making in a natural setting is defined in literature as a common function of task characteristics and decision-maker's knowledge and expertise with respect to the task (16). Drury et al. (13) and Priest and Gass (27) regard the judgement and decision-making processes of leaders and instructors of outdoor sports as a rational process while Galloway (16) views it as decision-making processes in a natural setting (6). study intends to demonstrate the impact of mental toughness of athletes doing outdoor sports on their decision-making skills.It's thought that the research will outdoor guide the leaders of outdoor sports and contribute to the development of mental skills. In this context, the following questions are tried to be answered. (10).

1. Do demographic variables affect decision making and mental endurance?

2. Is there a relation between mental endurance and decision making?

3. Is mental endurance significant in outdoor sports?

4. Is decision making skill is significant in outdoor sports?

\section{MATERIAL AND METHOD}

\section{Method}

Outdoor sports have been gaining popularity in Turkey through festivals, contests and organizations. Through these contests and festivals, performers of outdoor sports also find a chance to improve themselves. The study uses the survey collection technique, a quantitative research method.

\section{Population and Sample}

The study population is composed of outdoor athletes in Turkey while the study sample is made up of randomly selected performers of outdoor sports from the cities of Eskişehir, İstanbul, Konya, İzmir, Malatya, Mersin, Adana, Gaziantep, Kayseri, Antalya and Trabzon. It has been assumed that the cities chosen as the study's sample contain large numbers of outdoor sports performers. A total of 504 people (330 men, 174 women) were included in the study, $23.2 \%$ of whom do mountain climbing, $41.3 \%$ hiking, $6.5 \%$ paragliding, $2.2 \%$ caving, $11.9 \%$ mountain biking, $8.1 \%$ rock climbing and $6.7 \%$ other sorts of outdoor sports.

\section{Data Collection Tool}

In order to determine the mental toughness of individuals engaged in outdoor sports, the mental toughness in sports scale developed by Sheard et al. (29) and adapted to Turkish by Altıntaş and Bayar Koruç (1) was used and the Melbourne Decision Making Scale I-II Scale developed by 
Mann et al. (35) and adapted to Turkish by Deniz (11) was used in order to examine the athletes' decision-making ability.

The mental toughness scale in sports consists of 3 sub-sets, which are: confidence, control and continuity. "Confidence" refers to belief in one's talents and seeing oneself above competitors to reach the target in challenging situations. "Continuity" means taking responsibility, concentrating, and not giving up to achieve the goals set (30), while "control" refers to keeping composure, maintaining calm and being comfortable in the face of pressure or unexpected situations (30). Confidence is made up of items 1 , $5,6,11,13,14$, continuity $3,8,10,12$ and control 2 , $4,7,9(29)$.

The Melbourne Decision-Making scale has two parts. Part 1 : aims to determine self-respect (self-confidence) in decision-making. It consists of 6 items in total, and the three items (2-4-6.) are scored reversely. The scoring is made on the basis of the answers "True" ( 2 points), "True in certain situations" (1 point) and "Not true" (0 points). The highest score on the scale is 12 , and high scores indicate a high level of self-esteem when making decisions. Part II consists of 22 items and measures decision-making styles and has 4 subfactors, which are Attentive, Evasive, Procrastinative and Panic Decision Making. High scores indicate that the relevant decisionmaking style is used (11). The items that measure the sub-sets of decision-making styles are items 24-6-8-12 and 16 for careful decision-making, items 3-9-11-14-17 and 19 for evasive decision-making, items 5-7-10 -18 and 21 for procrastinative decision-making and items 1-13- 15-20 and 22 for panic decision making. The lowest score for careful and evasive decision- making is 0 , and the highest score is 12 , and the lowest score is 0 and the highest score is 10 for procrastinative and panic decision-making (11).

\section{Data Collection}

Information such as the purpose of the research, how the questionnaire form is to be marked and what should be paid attention in marking and the name, surname and title of the person conducting the research and of the consultant and the name of the organization where they work was given on top of the questionnaire forms used in the research. The scale was applied to outdoor sports athletes in 2017. The scale was applied by the researchers during climbing and in training camps on those who voluntarily participated in the research.

\section{Reliability and Validity Analyses of Data Collection Tool}

For general reliability, Cronbach's Alpha coefficient was calculated. The most common method used in the examination of reliability is Cronbach's Alpha coefficient. Significance was defined as $p<0.05$ and $p<0.01$. Reliability is a concept that includes the consistency and validity of all the questions and the homogeneity to measure the formation. The method improved to evaluate the reliability of the tests is defined as reliability analysis and the evaluation of the questions is entitled as question analysis. The most widely used method to determine the reliability is Cronbach's Alpha coefficient. Cronbach's Alpha is;

$0.60 \leq \alpha<0.80$ scale is quite reliable

$0.80 \leq \alpha<1.00$ scale is highly reliable

In our study, Cronbach's Alpha Value of the scale was calculated as 0.80 (mental toughness) and .79 (decision-making).

\section{Data Analyses}

The data collected in the study were analyzed using the statistical package program (SPSS 22.0), after which the results were interpreted. The data showed a normal and homogeneous distribution. The Independent samples $t$ test was used when reviewing the relationship between data and demographic variables and comparing quantitative data between the groups. Kolmogorov-Smirnov and Shapiro-Wilk normality tests were performed in order to determine whether research data shows a normal distribution or not. It was given a look to Kurtosis-Skewness values for data sets that do show a normal distribution and it is assumed that data showed normal distribution because the values are between $+1 /-1$. Where there were more than two groups, the One Way ANOVA test was used for comparison of parameters between groups. Correlation analysis was performed to measure the relationship between mental toughness and decision-making skills in sports. 


\section{Results}

This study, the variables gender, age, educational status, marital status, the type of outdoor sport done and experience with outdoor sports were examined and statistically significant differences were founded.

\begin{tabular}{|c|c|c|c|c|c|c|c|}
\hline & & Gender & $\mathbf{N}$ & Mean & SD & $t$ & $p$ \\
\hline \multirow{6}{*}{ 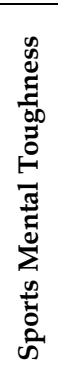 } & & Male & 330 & 3.0571 & .45725 & & \\
\hline & Confidence & Female & 174 & 2.8238 & .44538 & 5.495 & $.000^{*}$ \\
\hline & & Male & 330 & 2.5894 & .34369 & & \\
\hline & Constancy & Female & 174 & 2.5675 & .40154 & .610 & .542 \\
\hline & & Male & 330 & 2.3818 & 63075 & & \\
\hline & Control & Female & 174 & 2.5330 & .67253 & -2.501 & $.013^{*}$ \\
\hline \multirow{10}{*}{ 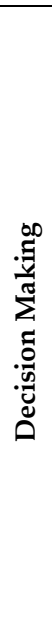 } & & Male & 330 & ,9854 & .22665 & & \\
\hline & Self-confidence & Female & 174 & .9119 & .24419 & 3.368 & $.001^{*}$ \\
\hline & & Male & 330 & 1.6253 & .36934 & & \\
\hline & $\begin{array}{l}\text { CarefulDecision } \\
\text { MakingStyle }\end{array}$ & Female & 174 & 1.6743 & .30243 & -1.602 & .110 \\
\hline & \multirow[b]{2}{*}{$\begin{array}{c}\text { Avoidant Decision Making } \\
\text { Style }\end{array}$} & Male & 330 & .6884 & .41941 & & \\
\hline & & Female & 174 & .6379 & .44994 & 1.252 & .211 \\
\hline & \multirow[b]{2}{*}{$\begin{array}{c}\text { ProcrastinationDecision } \\
\text { Making Style }\end{array}$} & Male & 330 & .5848 & .42464 & & \\
\hline & & Female & 174 & .6345 & .44197 & -1.230 & .219 \\
\hline & \multirow[b]{2}{*}{$\begin{array}{c}\text { Panicky Decision Making } \\
\text { Style }\end{array}$} & Male & 330 & .5915 & .47367 & & \\
\hline & & Female & 174 & .6552 & ,43510 & -1.475 & .141 \\
\hline
\end{tabular}

When mental endurance and decision making skills are examined according to gender of outdoor athletes in Table 1, statistically significant differences have been found in trust, control and self-esteem dimensions. According to these results men believe in their mental abilities and think that they are better than their opponents. Women are better at remaining calm, controlled and relaxed (30).

\begin{tabular}{|c|c|c|c|c|c|c|c|c|}
\hline & & Age & $\mathrm{N}$ & Mean & SD & $\mathrm{F}$ & $\mathrm{P}$ & Difference \\
\hline \multirow{15}{*}{ 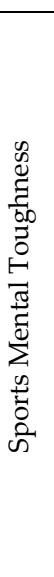 } & \multirow{6}{*}{ Confidence } & 18-21 age & 232 & 2.8764 & .46582 & \multirow{6}{*}{8.686} & \multirow{6}{*}{$.000^{*}$} & \\
\hline & & $22-25$ age & 124 & 2.9476 & .46677 & & & $3-1$ \\
\hline & & 26-29 age & 54 & 3.0895 & .38813 & & & $6-1$ \\
\hline & & $30-33$ age & 11 & 3.0455 & .21201 & & & $6-2$ \\
\hline & & 34-37 age & 22 & 3.0530 & .37581 & & & $6-3$ \\
\hline & & 38 age + & 61 & 3.2760 & .45122 & & & $6-5$ \\
\hline & \multirow{6}{*}{ Constancy } & $18-21$ age & 232 & 2.6250 & ,37725 & \multirow{6}{*}{7,755} & \multirow{6}{*}{$.000^{*}$} & 1-3. 1-4 5-1. \\
\hline & & $22-25$ age & 124 & 2,6089 & ,35390 & & & $1-6$ \\
\hline & & 26-29 age & 54 & 2,4537 & 30357 & & & $2-3.2-4$ \\
\hline & & $30-33$ age & 11 & 2,2273 & ,30526 & & & 5-2. $2-6$ \\
\hline & & $34-37$ age & 22 & 2,8068 & 36131 & & & 5-3. 3-4 \\
\hline & & 38 age + & 61 & 2,4590 & 29290 & & & $5-4.6-4$ \\
\hline & \multirow{3}{*}{ Control } & 18-21 age & 232 & 2,5938 & ,58164 & \multirow{3}{*}{17,800} & \multirow{3}{*}{$.000^{*}$} & $1-3.1-4$ \\
\hline & & $22-25$ age & 124 & 2,5948 & ,56453 & & & $1-5.1-6$ \\
\hline & & 26-29 age & 54 & 2,0880 & 66616 & & & $2-3.2-4$ \\
\hline
\end{tabular}




\begin{tabular}{|c|c|c|c|c|c|c|c|c|}
\hline & & $30-33$ age & 11 & 1,7955 & 67840 & & & $2-5,2-6$ \\
\hline & & 34-37 age & 22 & 2,1477 & ,73864 & & & \\
\hline & & 38 age+ & 61 & 2,0246 & ,61527 & & & \\
\hline \multirow{30}{*}{ 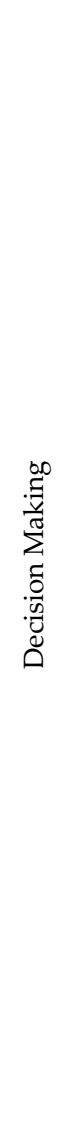 } & \multirow{6}{*}{ Self-confidence } & $18-21$ age & 232 & .9346 & .23192 & \multirow{6}{*}{1.139} & \multirow{6}{*}{.338} & \\
\hline & & $22-25$ age & 124 & .9718 & .26435 & & & \\
\hline & & 26-29 age & 54 & .9907 & .15329 & & & \\
\hline & & $30-33$ age & 11 & .9545 & .21201 & & & \\
\hline & & 34-37 age & 22 & 1.0000 & .24125 & & & \\
\hline & & 38 age+ & 61 & .9918 & .24424 & & & \\
\hline & \multirow{6}{*}{$\begin{array}{l}\text { Careful Decision } \\
\text { MakingStyle }\end{array}$} & $18-21$ age & 232 & 1.6961 & .28209 & \multirow{6}{*}{3.846} & \multirow{6}{*}{$.002^{*}$} & \multirow{6}{*}{$\begin{array}{c}1-2.1-4 \\
1-6.5-4 \\
5-6\end{array}$} \\
\hline & & $22-25$ age & 124 & 1.6035 & .41352 & & & \\
\hline & & 26-29 age & 54 & 1.6173 & .27592 & & & \\
\hline & & 30-33 age & 11 & 1.4545 & .34230 & & & \\
\hline & & 34-37 age & 22 & 1.7500 & .37001 & & & \\
\hline & & 38 age+ & 61 & 1.5328 & .43228 & & & \\
\hline & \multirow{6}{*}{$\begin{array}{l}\text { Avoidant Decision } \\
\text { Making Style }\end{array}$} & 18-21 age & 232 & .8211 & .44729 & \multirow{6}{*}{15.466} & \multirow{6}{*}{$.000^{*}$} & \\
\hline & & $22-25$ age & 124 & .6492 & .40537 & & & $1-2.1-3$ \\
\hline & & 26-29 age & 54 & .4105 & .28172 & & & $1-4.1-5$ \\
\hline & & 30-33 age & 11 & .5455 & .21201 & & & $1-6.2-3$ \\
\hline & & 34-37 age & 22 & .5076 & .26961 & & & $2-6$ \\
\hline & & 38 age + & 61 & .4563 & .36629 & & & \\
\hline & \multirow{6}{*}{$\begin{array}{l}\text { Procrastination } \\
\text { Decision Making } \\
\text { Style }\end{array}$} & 18-21 age & 232 & .6500 & .44420 & \multirow{6}{*}{3.113} & \multirow{6}{*}{$.009^{*}$} & \multirow{6}{*}{$\begin{array}{l}1-3.1-5 \\
2-3.2-5\end{array}$} \\
\hline & & $22-25$ age & 124 & .6274 & .43530 & & & \\
\hline & & 26-29 age & 54 & .4630 & .39778 & & & \\
\hline & & $30-33$ age & 11 & .7091 & .38329 & & & \\
\hline & & $34-37$ age & 22 & .4091 & .33510 & & & \\
\hline & & 38 age+ & 61 & .5410 & .39723 & & & \\
\hline & \multirow{6}{*}{$\begin{array}{l}\text { Panicky Decision } \\
\text { Making Style }\end{array}$} & 18-21 age & 232 & .7517 & .42160 & \multirow{6}{*}{15.770} & \multirow{6}{*}{$.000^{*}$} & \multirow{6}{*}{$\begin{array}{l}1-2.1-3 \\
1-5.1-6 \\
2-3.2-5 \\
2-6.4-3 \\
4-5.4-6\end{array}$} \\
\hline & & $22-25$ age & 124 & .6323 & .46004 & & & \\
\hline & & $26-29$ age & 54 & .4333 & .51943 & & & \\
\hline & & 30-33 age & 11 & .7273 & .28667 & & & \\
\hline & & $34-37$ age & 22 & .2273 & .29790 & & & \\
\hline & & 38 age + & 61 & .3279 & .37244 & & & \\
\hline
\end{tabular}

Outdoor athletes' mental endurances and decision making skills are examined in Table 2. There are statistically significant differences among in mental endurance's subcategories; trust, continuity and control. There are statistically significant differences among decision making subcategories; careful decision making style, avoidant decision making style, procrastination decision making style and panicky decision making style. According to this, when age increases trust and continuity points increase as well. Youngsters have higher points for being controlled. In decision making, youngsters have more avoidant and panicky decision making style. 34-37 ages have more careful decision making style

Table 3. Distribution of the mental toughness and decision-making values of the athletes by the type of outdoor sports done

\begin{tabular}{|c|c|c|c|c|c|c|c|c|}
\hline & & $\begin{array}{c}\text { The Type Of } \\
\text { Outdoor Sports }\end{array}$ & $\mathrm{N}$ & Mean & SD & $\mathrm{F}$ & $P$ & Fark \\
\hline \multirow{12}{*}{ 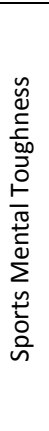 } & \multirow{7}{*}{ Confidence } & Rock climbing & 41 & 3.0772 & .49735 & \multirow{7}{*}{4.340} & \multirow{7}{*}{.000} & \\
\hline & & Mountaineering & $\begin{array}{c}41 \\
117\end{array}$ & 3.0385 & .45401 & & & 1-4. 1-6 \\
\hline & & Paragliding & $\begin{array}{c}111 \\
33\end{array}$ & 3.2424 & .35865 & & & 1-7. 3-2 \\
\hline & & Hiking & $\begin{array}{c}33 \\
208\end{array}$ & 2.9167 & .48460 & & & $2-4.2-6$ \\
\hline & & Caving & $\begin{array}{c}208 \\
11\end{array}$ & 3.1667 & .38006 & & & 2-7. 3-4 \\
\hline & & Mountain bike & $\begin{array}{l}11 \\
60\end{array}$ & 2.8944 & .42182 & & & 3-6. 3-7 \\
\hline & & Other & $\begin{array}{l}60 \\
34\end{array}$ & 2,8333 & .40410 & & & 5-7 \\
\hline & \multirow{5}{*}{ Constancy } & Rock climbing & 41 & 2,5976 & .42160 & & & \\
\hline & & Mountaineering & 117 & 2,6346 & .38358 & & & $1-7,2-7$ \\
\hline & & Paragliding & 33 & 2,5833 & .35171 & 2.165 & .045 & $4-7,5-6$ \\
\hline & & Hiking & 208 & 2,5781 & .35724 & & & 5-7 \\
\hline & & Caving & 11 & 2,7727 & .43952 & & & \\
\hline
\end{tabular}




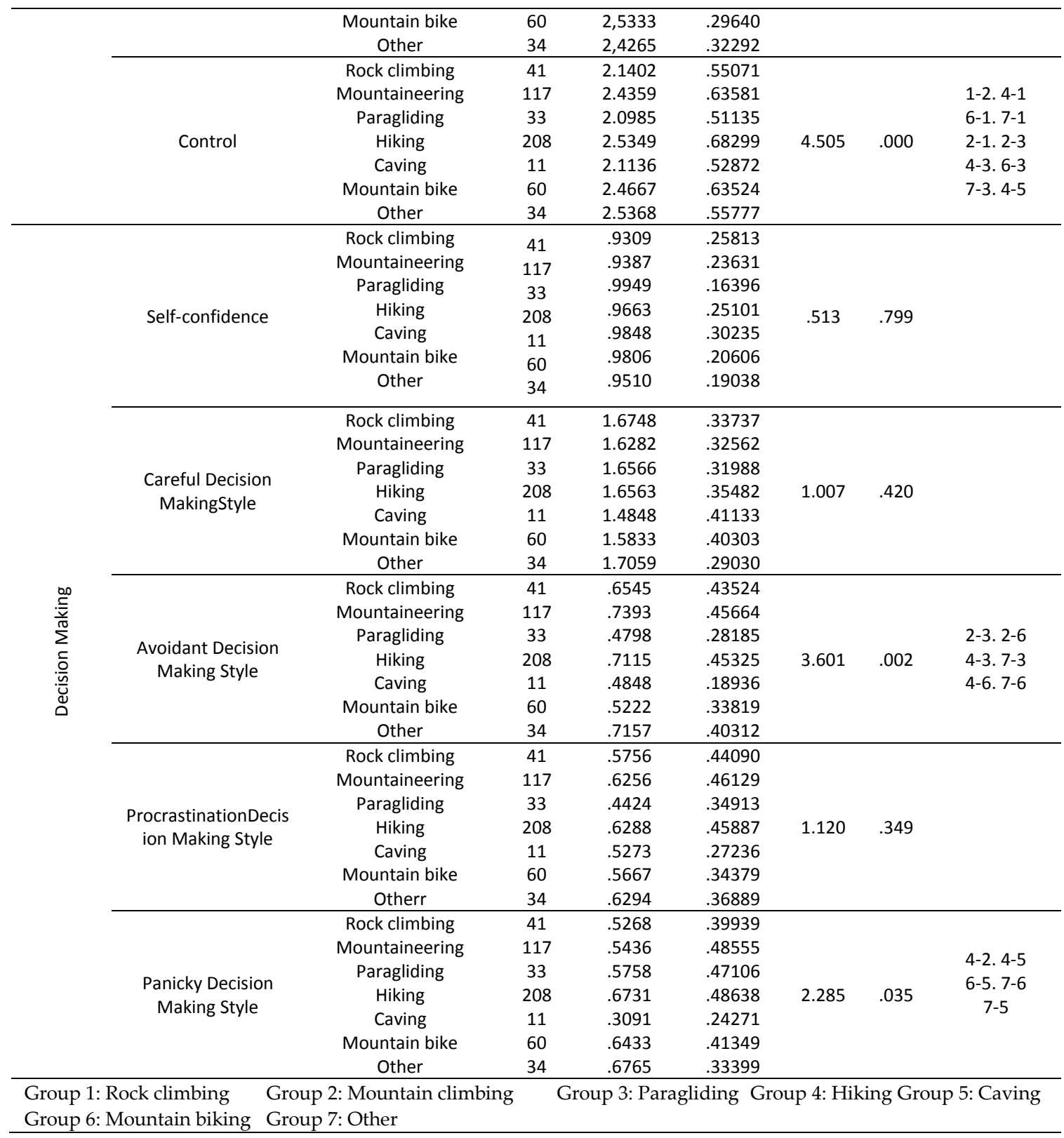

Mental endurance and decision making skills are examined according to the type of outdoor sports in Table 3. There are statistically significant differences among mental endurance substyles; trust, continuity and control. There are statistically significant differences among decision making subcategories; careful decision making style, avoidant decision making style, procrastination decision making style and panicky decision making style. According to this, in terms of mental endurance, paragliders $(X=3.24)$ believe in their ability and think that they are better than their opponents. Cavers $(X=2,77)$ are better in taking responsibility and concentrating, hikers $(X=2.53)$ are better to act calm under pressure or face with unexpected conditions. In decision making, while mountaineers have avoidant decision making style, hikers have panicky decision style. 


\begin{tabular}{|c|c|c|c|c|c|c|c|c|}
\hline & & Experience & $\mathrm{N}$ & Mean & $\mathrm{SD}$ & $\mathrm{F}$ & $\mathrm{P}$ & Difference \\
\hline \multirow{12}{*}{ 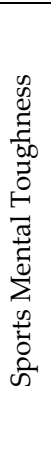 } & \multirow{4}{*}{ Confidence } & 1-3 year & 307 & 2.9446 & .43808 & \multirow{4}{*}{4.017} & \multirow{4}{*}{.008} & \multirow{4}{*}{$4-1.4-2$} \\
\hline & & 4-7 year & 118 & 2.9647 & .56017 & & & \\
\hline & & 8-11 year & 59 & 3.0650 & .38658 & & & \\
\hline & & 12 year + & 20 & 3.2750 & .37179 & & & \\
\hline & \multirow{4}{*}{ Constancy } & 1-3 year & 307 & 2.6034 & .36840 & \multirow{4}{*}{10.547} & \multirow{4}{*}{.000} & \multirow{4}{*}{$\begin{array}{l}1-3.1-4 \\
2-3.2-4\end{array}$} \\
\hline & & 4-7 year & 118 & 2.6547 & .37399 & & & \\
\hline & & 8-11 year & 59 & 2.4237 & .28713 & & & \\
\hline & & 12 year + & 20 & 2.2875 & .09159 & & & \\
\hline & \multirow{4}{*}{ Control } & 1-3 year & 307 & 2.5529 & .59909 & \multirow{4}{*}{18.285} & \multirow{4}{*}{.000} & \multirow{4}{*}{$\begin{array}{l}1-3.1-4 \\
2-3.2-4\end{array}$} \\
\hline & & 4-7 year & 118 & 2.4280 & .72139 & & & \\
\hline & & 8-11 year & 59 & 2.0212 & .51963 & & & \\
\hline & & 12 year + & 20 & 1.8625 & .48310 & & & \\
\hline \multirow{20}{*}{ 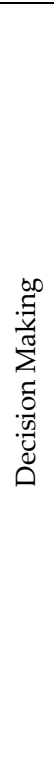 } & \multirow{4}{*}{ Self-confidence } & 1-3 year & 307 & .9636 & .24558 & \multirow{4}{*}{.955} & \multirow{4}{*}{.414} & \\
\hline & & 4-7 year & 118 & .9322 & .21817 & & & \\
\hline & & 8-11 year & 59 & .9831 & .19002 & & & \\
\hline & & 12 year + & 20 & 1.0000 & .28613 & & & \\
\hline & \multirow{4}{*}{$\begin{array}{c}\text { Careful Decision } \\
\text { MakingStyle }\end{array}$} & 1-3 year & 307 & 1.6477 & .30947 & \multirow{4}{*}{5.346} & \multirow{4}{*}{.001} & \multirow{4}{*}{$1-4.2-4.3-4$} \\
\hline & & 4-7 year & 118 & 1.6808 & .41321 & & & \\
\hline & & 8-11 year & 59 & 1.6356 & .34943 & & & \\
\hline & & 12year+ & 20 & 1.3500 & .37813 & & & \\
\hline & \multirow{4}{*}{$\begin{array}{c}\text { Avoidant Decision } \\
\text { Making Style }\end{array}$} & 1-3 year & 307 & .7389 & .42963 & \multirow{4}{*}{16.321} & \multirow{4}{*}{.000} & \multirow{4}{*}{ 1-3. 1-4. 2-3 } \\
\hline & & 4-7 year & 118 & .6864 & .44024 & & & \\
\hline & & 8-11 year & 59 & .3446 & .27831 & & & \\
\hline & & 12year+ & 20 & .5000 & .25363 & & & \\
\hline & \multirow{4}{*}{$\begin{array}{c}\text { ProcrastinationDe } \\
\text { cision Making } \\
\text { Style }\end{array}$} & 11-3 year & 307 & .6463 & .42173 & \multirow{4}{*}{6.199} & \multirow{4}{*}{.000} & \\
\hline & & $4-7$ year & 118 & .5966 & .47139 & & & \\
\hline & & 8-11 year & 59 & .3864 & .32348 & & & $1-3.2-3$ \\
\hline & & 12 year+ & 20 & .5900 & .43274 & & & \\
\hline & & 1-3 year & 307 & .7055 & .47754 & & & \\
\hline & Panicky Decision & 4-7 year & 118 & .5695 & .42537 & & & 1-2. 1-3. 1-4. \\
\hline & Making Style & 8-11 year & 59 & .3458 & .31695 & 16.612 & .000 & $2-3.2-4$ \\
\hline & & 12 year+ & 20 & .2500 & .17014 & & & \\
\hline
\end{tabular}

Mental endurance and decision making skills are examined according to experience in Table 4. There are statistically significant differences among mental endurance substyles; trust, continuity and control. There are statistically significant differences among decision making subcategories; careful decision making style, avoidant decision making style, procrastination decision making style and panicky decision making style. According to this, in terms of mental endurance, believing in abilities in tough times and to be better than opponents increase when experience increases (confidence).
Generally, continuity and control decreases when experience increases. 4-7 age athletes have more careful decision making style. Avoidant decision making, procrastination decision making and panicky decision making decrease when experience increases.

\begin{tabular}{|c|c|c|c|c|}
\hline & & Self-confidence & Decision Making & Mental Toughness \\
\hline \multirow{3}{*}{ Self-confidence } & $\mathrm{r}$ & 1 & & \\
\hline & $\mathrm{P}$ & & & \\
\hline & $\mathrm{N}$ & 504 & & \\
\hline \multirow{3}{*}{ Decision Making } & $\mathrm{r}$ & $106^{*}$ & 1 & \\
\hline & $\mathrm{P}$ & .017 & & \\
\hline & $\mathrm{N}$ & 504 & 504 & \\
\hline \multirow{3}{*}{ Mental Toughness } & $\mathrm{r}$ & $.298^{* *}$ & $.206^{* *}$ & 1 \\
\hline & $\mathrm{P}$ & .000 & .000 & \\
\hline & $\mathrm{N}$ & 504 & 504 & 504 \\
\hline
\end{tabular}


There is meaningful relation between mental endurance and decision making skill in Table 5 . There is a low positive relation between decision making and self-esteem $[\mathrm{r}=.106 ; \mathrm{p}<.05]$. There is a low positive relation between mental endurance

\section{Discussion and Conclusion}

This study intends to examine the impact of the mental toughness of athletes doing outdoor sports on their decision-making skills.

Spending time in nature is becoming a popular lifestyle in today's society. For this reason, it has become a necessity to produce a variety of programs, activities and projects in order to increase leisure time activities and expand their spectrum (23). In our study, the variables gender, age, educational status, marital status, the type of outdoor sport done and experience with outdoor sports were examined and statistically significant differences were found ( $\mathrm{p}<0.05)$.

Statistically significant differences were found in the subsets of mental toughness and selfconfidence (Decision Making) by the gender variable (table 1). Besides, men have higher levels of self-esteem at decision making.The main reason men are more into physical activities is because men's body structure is more robust than that of women (22). It can be assumed that due to this physical advantage, men mentally display a more confident attitude towards outdoor sports, that is to say men rely on their physical strength. There are studies that support this conclusion (37). Besides, being calm and even-tempered may have to do with women's personality traits. According to our study, mental toughness displays itself in the form of confidence for men and self-control for women. Men, therefore, believe in their skills to reach targets in challenging situations and think they are better (30) than other athletes. Women, on the other hand, tend to remain calm under pressure or in the face of unexpected situations (30). Psychological skills help athletes maximize their physical skills (39). As regards decision-making skills, men make decisions with more self-confidence than women. The fact that men are more confident with their decisions in outdoor sports than women may be due to their spending more time doing outdoor sports. Using psychological skills is important for athletes who are engaged in high-risk sports (26). and decision making [r=.206; $\mathrm{p}<.01]$. There is a low positive relation between mental endurance and self-esteem [r=.298; $\mathrm{p}<.01]$. In general. it could be said that there is a relation between mental endurance decision making.

Mental toughness is a concept with different impact dynamics that changes depending on the sports branch according to the general view (18). According to our study, mental toughness displays itself in the form of confidence for men and self-control for women in outdoor sports. As regards decision-making skills, men make decisions with more selfconfidence.

Statistically significant differences were found in the subsets of mental toughness and decision-making by the age variable (table $2)(p<.001)$. In our study, as age increases in the subsets of confidence and continuity, so does mental toughness and as age decreases, control behaviors increase. In other words, as age increases, it can be said that the strength for reaching the targets in challenging circumstances, believing in one's talents, taking responsibility in line with the targets set, focusing, as well as the strength for fighting for an end increases. Young people, on the other hand, tend to remain calm under pressure or in the face of unexpected situations (30). Haran Larre (20) has found that two-thirds of accidents that occur during hiking affect people at the age of 50 and over. In such cases, progression of age constitutes a risk, and mental toughness gains more importance for the elderly. Decision-making is thought to have an important place in outdoor sports. In terms of decision-making, the results look more favorable for young people. Bull et al. (3) noted that good judgment impacts on coping under pressure. Decision-making skills have emerged as a more decisive trait for young people. This can be explained by the fact that young people are more enthusiastic and driven to prove themselves.

According to the type of outdoor sports done (Table 3), statistically significant results have been obtained in mental toughness and decision-making skills ( $p$ <.001). We have also found that of the outdoor sports studied, those who are engaged in paragliding, mountain 
climbing, rock climbing and caving take more responsibility, have more of a fighting spirit and believe in their ability to reach their targets (29), while those who go hiking keep their calm under pressure or in the face of unexpected situations (29). It is thought to be an expected feature to be a fighter for those involved in sports such as rock climbing, paragliding and mountain climbing. Being mentally durable in these sports is particularly determinant to success. Inevitably dangerous high-risk sports are distinguished from traditional sports by the environment they are performed in (26). Nicholls et al. (37) did not find any significant differences in mental toughness by the kind of sports played. Fourie and Potgieter (15) examined mental toughness and its components and collected them under 12 headings. This includes mental toughness. Statistically significant results were found between evasive decision-making and panic decisionmaking. Accordingly, mountain climbers and hikers make more evasive decisions. Doing risky sports requires the ability to keep composure in stressful situations, to overcome difficulties, to cope with emotional and physical discomfort, to be decisive in tough conditions, and to be able to cope with frightening situations (39). These skills are also thought to have an impact on decision making. It is known that outdoor sports are risky sports. According to Galloway (16), decision-making is an important skill. Decision-making is especially important for those who guide large groups. Adventure sports guides should have the ability to reason effectively about the risk levels, the potential benefits of the situation and the possible consequences (5).

As experience has increased (table 4), the belief in mental toughness and abilities and the belief that one is better than his/her opponents have increased, and it has been seen that taking responsibility and concentrating and keeping composure in the face of challenging or unexpected situations, being in controlled and the sense of comfort decreased. According to these results, experience has an important influence on mental toughness. Increased experience in athletes is a behavior that affects their ability to believe in their abilities. This will lead to success at the end of a mental process. That kind of toughness will create the right decision making mechanism. According to some studies, more than one-third of the victims who suffered trauma as a result of an accident while doing outdoor sports had little or no experience in mountain sports (20). Connaughton et al. (8) reported that competition- based experience was an important factor in the development of mental toughness for the athletes. In addition, mental toughness can be regarded as an important attribute when the difficulties of outdoor sports are considered. In one study, Nicholls et al. (37) found significant results with regard to mental toughness and the fighting spirit based on experience. According to our results, the more the experience, the more trust athletes have in their talents. This may be related to the fact that these athletes have gained valuable experiences following the accidents they have seen and experienced. According to our findings, as experience increases, evasive decision-making, deferential decision-making and panic decision-making decrease. This can be explained by the fact that outdoor sports require a sudden decisionmaking ability. Because there is uncertainty in outdoor sports, this uncertainty forces leaders or individuals to make sudden decisions. Negative experiences and confidence building result in attainment of goals. This will provide opportunities for personal development and enable learning of important lessons (9). According to the research, as the number of climbing increases, it develops in physical and psychological characteristics (40). Contrary to what was expected in our study, as experience increased, there was a decrease in the careful decision making sub-dimension.

This can be explained by the athletes taking no responsibility under difficult conditions. Being mentally strong and coping with challenges in nature helps achieve success (4). Decision-making in this process can have a positive impact on mental strength. According to Galloway (16), in emergencies, the rate of highly experienced leaders being influenced by the group decreases. Accordingly, having a high level of experience has an important impact on decision-making.

When Table 5 was examined, a positive correlation was seen between mental toughness, decision-making ability $(\mathrm{r}=.206, \mathrm{p}$ $<.000)$ and self-confidence $(\mathrm{r}=.106, \mathrm{p}<.017)$. Accordingly, though not very much so, mental toughness affects decision-making and selfconfidence positively. Making the right decisions increases the person's trust in 
themselves. This also affects self-confidence. Draper et al. (12) concluded that stress affects rock climbing psychologically. This type of stressful situation can affect the mental toughness and the ability to make a decision to achieve a goal. In general, when looking at the profiles of mountain and nature athletes, it is seen that age, experience, and gender have an impact on accidents. People who are experienced and experts in their fields have been found to be exposed to more accidents (32). As a result, it can be said that as mental toughness increases, so do decision-making skills and confidence, that is to say. Decision making in outdoor athletes is an important skill (19).

\section{Conclusion}

Mental toughness has an important influence on outdoor sports. It has a direct influence on reaching

\section{REFERENCES}

1. Altıntaş, A.\&Bayar Koruç, P. (2016). SpordaZihinselDayanıklılıkEnvanteri'ninPsikometrikÖzellikle rininİncelenmesi.Hacettepe Journal of Sport Sciences, 27(4), 162-171.

2. BMC. (2006). Annual Report. British Mountaineering Council, Manchester,UK.

3. Bull, S., Shambrook, C., James, W.\& Brooks, J. (2005). Towards an understanding of mental toughness in elite English cricketers. Journal of Applied Sport Psychology, 17, 209-227.

4. Burke, S.M.\&Orlick, T. (2003). "Mental Strategies of Elite High Altitude Climbers: Overcoming Adversity on Mount Everest.Journal of Human Performance in Extreme Environments, 7(2), 15-22.

5. Collins, L.\& Collins, D. (2013). Decision Making and Risk Management in Adventure Sports Coaching. Quest, 65(1), 7282.

6. Collins, L.\& Collins, D. (2016). Professional judgement and decision making in the planning process of high-level adventure sports coaching practice.Journal of Adventure Education and Outdoor Learning, 16(3), 256-268.

7. Cordell, H.K. (2008). The latest trends in nature-based outdoor recreation. Forest history today, Spring, 7-8.

8. Connaughton, D., Wadey, R., Hanton, S.\& Jones, G. (2008). The development and maintenance of mental toughness: Perceptions of elite performers. Journal of Sports Sciences, 26, 83-95.

9. Crust, L. \& Clough, P.J. (2011). Developing mental toughness: From research to practice. Journal of Sport Psychology in Action, (2), 21-32.

10. Crust,L. \&R, Keegan. (2010). Mental toughness and attitudes to risk-taking.Personality and Individual Differences, 49,164-168.

11. Deniz, M.E. (2004). Investigation Of The Relation Between Decision Making Self-Esteem, Decision Making Style And Problem Solving Skills of University Students. Eurasian Journal of Educational Research, 15, 23-35.

12. Draper, N., Jones, G.A., Fryer, S., Hodgson, C. \& Blackwell, G. (2008). Effect of an on-sight lead on the physiological and psychological responses to rock climbing.Journal of Sports Science and Medicine, 7, 492-498. the target. Decision-making also emerges as a critical skill when it is thought that outdoor sports are carried out under difficult conditions and the risk of accidents is high. In general, demographic variables influence mental toughness and decision-making. It should be noted that decision-making ability increases as mental toughness increases. Accordingly, decision-making becomes more important for sportsmen, especially those who lead crowded groups. The right decisions will make the group feel safe. It is suggested that individuals at every age, gender should be steered to do outdoor sports, places and stage for outdoor sports. In addition, relaxation exercises can be performed.

13. Drury, J., Bonney, B., Berman, D., \&Wagstaff, M. (2005). The back country classroom: Lesson plans for teaching in the wilderness (2nd ed.). Guilford, CY: The Globe Pequot press.

14. Egan, S. \&Stelmack, R.M. (2003). A personality profile of Mount Everest climbers. Personality and Individual Differences, 34(8), 1491-1494.

15. Fourie, S. \&Potgieter, J.R. (2001). The nature of mental toughness in sport.South African Journal for Research in Sport, Physical Education and Recreation, 23(2), 63-72.

16. Galloway, S.P. (2007). Experience and Medical DecisionMaking in Outdoor Leaders. Journal of Experiential Education, 30(2), 99-116.

17. Godbey, G. (2009). Outdoor Recreation, Health, and Wellness. Understanding and Enhancing the Relationship. Resources for the Future. May.1-29.

18. Gucciardi, D.F. \&Gordon, S. (2009). Development and preliminary validation of the cricket mental toughness inventory (CMTI). Journal of Sport Sciences, 27, 1293-1310.

19. Gürer, B. (2012). Investigating the leadership skills in outdoor sports \& search and rescue. AbantİzzetBaysal University.

20. Haran Larre, T. (2011). Accidentologie de la randonnéepédestre en moyennemontagne en Pays Basque Nord. Perspectives de prévention, observation de la population des randonneurs accidents en saisonestivale de 2006 a 2009. Doctor of Medicine thesis, Bordeaux 2 University.

21. Jones, G., Hanton, S., \&Connaughton, D. (2007). A framework of mental toughness in the world's best performers. The Sport Psychologist, 21, 243-264.

22. Kane, M.J. (1990). Female Involvement in Physical Recreation: Gender Role as Constraint. Journal of Physical Education, Recreation and Dance, (61), 52-56.

23. Kelly, J.R. (1990). Leisure. Englewood, Cliffs,New Jersey: Prentice-Hall.

24. Kuru, E. (2000). Spordapsikoloji. Ankara: Gazi Üniversitesi Basımevi.

25. Luthans, F. (2002). Positive Organizational Behavior: Developing and Managing Psychological Strengths.Academy of Management Executive, 16(1), 57-72.

26. O'Keeffe, K. (2016). The mental strategies of elite climbing Sherpa., Master's Thesis in Sport and Exercise Psychology,Department of Sport Sciences, University of Jyväskylä, 102 pages. 
27. Priest, S., \&Gass, M. A. (2005). Effective leadership in adventure programming (2nd ed.). Champaign, IL: Human Kinetics

28. Puchan, H. (2005). "Living "extreme": Adventure sports, media and commercialisation", Journal of Communication Management, 9(2), 171-178.

29. Sheard, M., Golby, J. \& Van Wersch, A. (2009). Progress towards construct validation of the Sports Mental Toughness Questionnaire (SMTQ). European Journal of Psychological Assessment, 25, 186-193.

30. Sheard, M. (2013). Mental Toughness: The Mindset Behind Sporting Achievement. Second Edition, Hove, East Sussex: Routledge.

31. Smits, B.L.M., Pepping, G.J. \&Hettinga, F.J. (2014). Pacing and Decision Making in Sport and Exercise: The Roles of Perception and Action in the Regulation of Exercise Intensity. Sports Med,44,763-775.

32. Soulé, B., Lefèvre, B., Boutroy, E., Reynier, V., Roux, F. \&Corneloup, J. (2014). Accidentology of mountain sportsSituation review \& diagnosis, PetzlFondation, December.

33. Maddi, S.R. (2004). Hardiness: An operationalization of existential courage. Journal of Humanistic Psychology, 44(3), 279-298.

34. McKenzie, M.D. (2000). How are adventure education program outcomes achieved?: A review of the literature. Australian Journal of Outdoor Education, (5)1, 19-28.
35. Mann, L., Radford, M., Burnett, P., Ford, S., Bond, M., Leung, K., Nakamura, H., Vaughan, G. \& Yang, K.S. (1998). “CrossCultural Differences in Self-Reported Decision-Making Style and Confidence". International Journal of Psychology, 33(5), 325-335.

36. Marco, C.D., Hartung, P.J. \&Nevmanl, P.P. (2003). Validitiy of the Decisional Process Inventory. Journal of Vocational Behavior, 6, 1-19.

37. Nicholls, A.R.,Polman, R.C.J., Levy, A.R. \& Backhouse, S.H (2009). Mental toughness in sport: Achievement level, gender, age, experience, and sport type differences. Personality and Individual Differences, 47, 73-75

38. Voigt, D. (1998). SporSosyolojisi, KurtişMatbaacılık, İstanbul, 94

39. Young, P.R.\& Knight, E.L. (2014). Use of psychological skills by risk sport athletes.Journal of Human Performance in Extreme Environments, 11(2), Article 2.

40. Woollings, K., McKay., C., Kang., J., Meeuwisse., W., C.A Emery., CA. (2014). Injury Rates, Mechanisms, And Risk Factors For Injury In Youth Rock Climbers. British Journal of Sports Medicine. (48): 672. 